Potravinarstvo Slovak Journal of Food Sciences

vol. 15, 2021, p. 1039-1048

https://doi.org/10.5219/1658

Received: 25 June 2021. Accepted: 30 September 2021. Available online: 28 October 2021 at www.potravinarstvo.com

(C) 2021 Potravinarstvo Slovak Journal of Food Sciences, License: CC BY 4.0

ISSN 1337-0960 (online)

\title{
EFFECT OF RAW PEARL MILLET FLOUR INCLUSION ON THE QUALITY AND FORMULATION COST OF BEEF SAUSAGES
}

\author{
Fredrick Adzitey, Joseph Yaro, Joseph Kudadam Korese, Mohammad Halim Jeinie, Nurul Huda
}

\begin{abstract}
This study investigated the sensory, nutritional, and physicochemical characteristics as well as formulation cost of beef sausages formulated with raw pearl millet flour (RaPMF) as an extender. Four treatments were formulated with $0 \%, 5 \%$, $10 \%$ and $15 \%$ RaPMF. Ash, carbohydrate, fat, and protein contents of the beef sausages were not influenced $(p<0.05)$ by the RaPMF. The calcium, magnesium, potassium, and $\mathrm{pH}$ contents were highest $(p<0.05)$ in the $15 \%$ RaPMF beef sausages. Cooking loss was at least $(p<0.05)$ for the $15 \%$ RaPMF beef sausages. Formulation of beef sausages with RaPMF did not affect $(p>0.05)$ the sensory properties (week 1 ), water holding capacity, peroxide value, lightness (week 1), and yellowness (week 1). The formulation cost was least for $15 \%$ RaPMF beef sausages and highest for $0 \%$ RaPMF beef sausages. As a general conclusion, RaPMF improved the mineral composition of the beef sausages and reduced production costs without compromising its physicochemical and sensory properties.
\end{abstract}

Keywords: beef sausages; nutrient composition; physicochemical properties; sensory analysis; pearl millet flour

\section{INTRODUCTION}

The quest and desire for meat products including beef sausages have increased due to their good taste, nutrient composition, and demand for ready-to-eat meals (Ossom et al., 2020a; Yadav and Yadava, 2008). The consumption of meat products is hampered by its associated health issues and high price (Battaglia et al.., 2015). These have limited their purchase and consumption to mostly middle and highincome earners (Ossom et al., 2020a; Stubbs et al., 2002). The development and formulation of meat products that are cheaper with better nutrient composition is the way forward. This can be achieved by the use of extenders.

Extenders are food ingredients that are not of meat origin but have an appreciable amount of proteins used in the formulation of meat products to partially replace muscle meat (Heinz and Hautzinger, 2007; Ossom et al., 2020b). They may play one or more of the following roles in meat products, thus, increase product volume, improve texture, produce healthy products, reduce the cost of production among others (Food and Agriculture Organization, 2013; Heinz and Hautzinger, 2007). For instance, Yadav and Yadava (2008) reported that the use of cornflour in quail meat rolls increased yield, and did not affect sensory properties at a $6 \%$ inclusion level. Also, sorghum flour as an extender in chicken patties promoted lower TBARS, and sensory properties were not significantly affected (Kumar et al., 2007). Pintado and Delgado-Pando (2020) indicated that the use of extenders provides opportunities for the formulation of healthier and more sustainable meat products.

Millets are cereal-grain crops widely grown and consumed in most parts of the world (Lang, 2020; Muthamilarasan et al., 2016). They are considered an essential cereal crop at the global level and have a significant economic impact especially in most developing countries (Lang, 2020; Nithiyanantham et al., 2019). Muthamilarasan et al. (2016) revealed that millets have gained popularity in the West because of their gluten-free, high protein, high fiber, and antioxidant contents. Millets are drought resistant, pest resistant, and can withstand poor soil conditions (Lang, 2020; Nithiyanantham et al., 2019). They are also a good energy crop for reducing malnutrition, potential prebiotic and probiotic, customary medicine, and a portion of vital food to preserve health (Lang, 2020; Muthamilarasan et al., 2016; Nithiyanantham et al., 2019). The cultivation of millet promotes sustainable production due to the aforementioned advantages. Therefore, using millet in the formulation of meat products such as sausages provides opportunities for diversification.

Beef sausages are meat products made from minced beef mixed with salt, spices, flavoring agents, and other ingredients such as bread crumbs or grains, and stuffed into casings (El-Magoli and Abd-Allah, 2014; Food and Agriculture Organization, 2020). When bread crumbs or grains are included, they act as extenders. 


\section{Figure 1 Raw pearl millet seeds.}
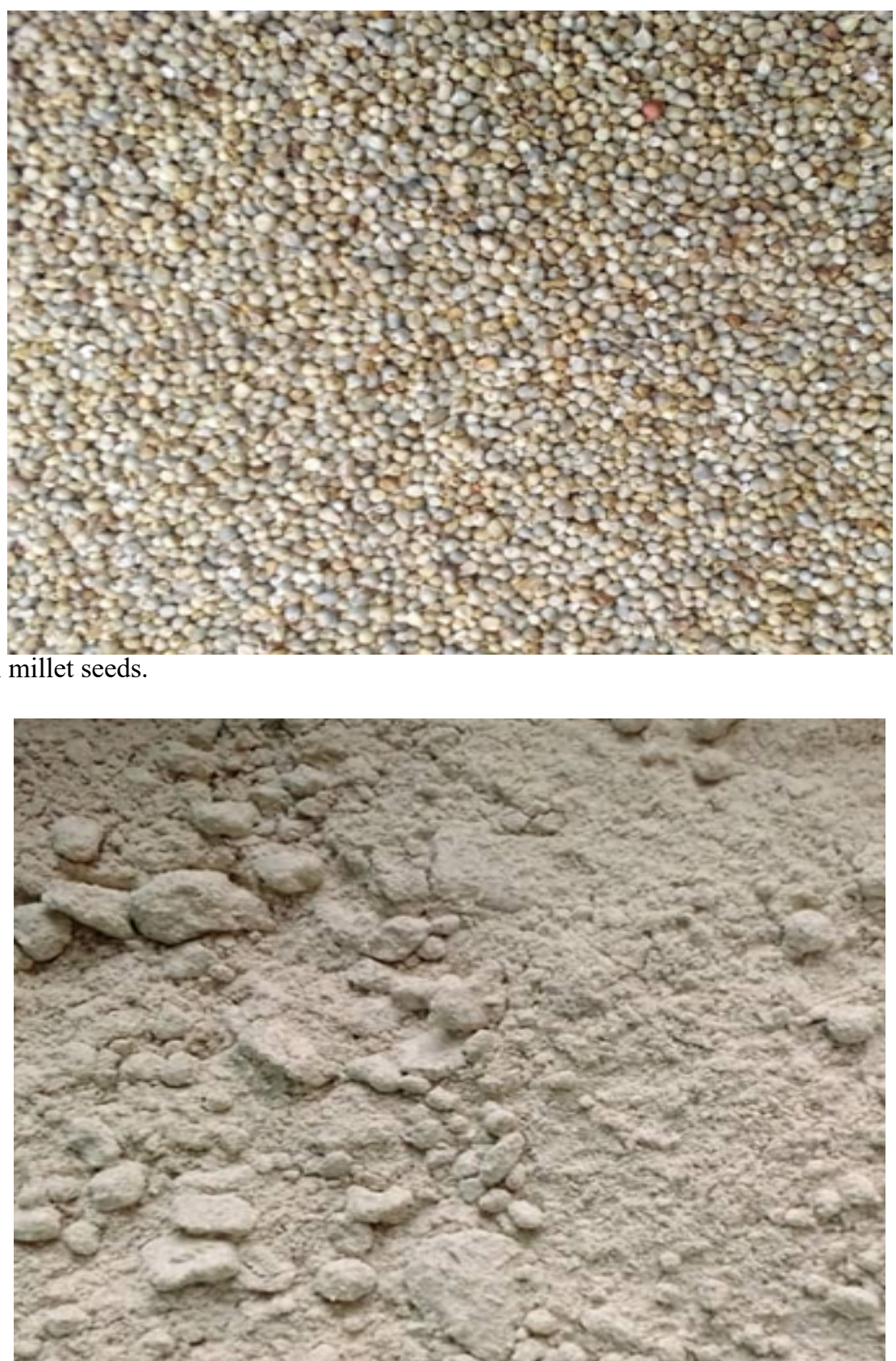

Figure 2 Pearl millet flour.

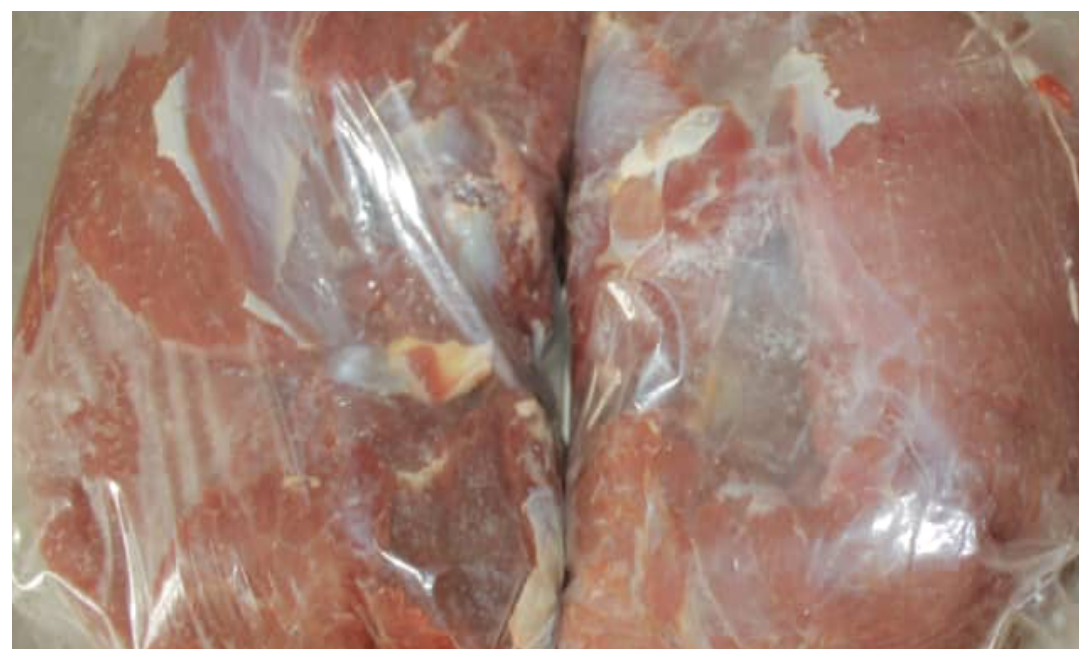

Figure 3 Beef sample used for this experiement 
Beef sausages are an important source of protein and other nutrients for humans and are normally consumed as a delicacy by many (Abu et al., 2019; Adua et al., 2020; Food and Agriculture Organization, 2020; Ossom et al., 2020a). Literature on the use of millet in formulating meat products is scarce, despite its importance and the role meat products play in the diet of humans. Therefore, this study investigated the influence of raw pearl millet flour on the sensory, nutritional, physicochemical, and formulation cost of beef sausages. The feasibility of utilizing raw pearl millet flour in formulating nutrient-rich and low-cost beef sausages will be helpful to expand its further application in the meat industry.

\section{Scientific hypothesis}

The hypothesis is based on the assumption that millet can be used to produce beef sausages that will have a positive effect on chemical and sensory acceptability. It also assumes that sausages prepared from millet could influence production cost. The results showed that pearl millet improved the mineral composition of the beef sausages and reduced cooking loss at the highest inclusion level. Millet reduced the production cost of the sausages.

\section{MATERIAL AND METHODOLOGY}

\section{Samples}

The samples used in this study were raw pearl millets, millet flour, and beef. The raw pearl millets (RaPM) were bought from the Aboabo market in the Tamale metropolis of Ghana, while the beef was bought from the University for Development Studies Meats Unit. Figures 1 and Figure 2 shows raw millet seeds and millet flour, respectively. Figure 3 shows a sample of the meat used for this study.

\section{Chemicals}

The chemical used were perchloric acid $(70 \%$ Purity, Chem-Lab, Belgium), Sodium Thiosulphate (99\% Purity, Lobachemie, India), hydrogen peroxide (35\% Purity, Chem-Lab, Belgium), acetic acid ( $>99.7 \%$ Purity, Daejung, Korea), chloroform ( $>99.5 \%$ Purity, Daejung, Korea), potassium iodide (99.7\% Purity, VWR Prolabo, Belgium), Sulphuric acid (98\% Purity, Merck, Germany).

\section{Animals and Biological Material}

Animals or biological materials were not used in this study.

\section{Instruments}

The instruments used in this study were mincer (Model star, Telleres Rammon, Spain), bowl chopper (Model 30, Telleres Rammon, Spain), hydraulic stuffer (Model 30, Telleres Rammon, Spain), smoker (Model HCR700L, ABAD, aquinaria (LAINT), Spain), colorimeter (CR 400 Konica Minolta Inc, Japan), pH meter (Crison Basic 20, Alella, Spain), atomic absorption spectrometer (AAS model novAA 400 P, Analytik Jena AG, Germany), centrifuge (Hettich ROTOFIX 32A Centrifuge, Germany), electric oven (Turbofan Blue Seal, UK), Kjeldahl apparatus (VELP Scientifica, 482365, Italy), Soxhlet apparatus (PRO-NITRO II, 0453462, J. P Selecta, Spain), Furnace (Select- Horn, 0453077, J.P Selecta, Spain) and oven dryer (0453598, J. P Selecta, Spain).

\section{Laboratory Methods}

The RaPM was hand-picked to remove visible debris and washed thoroughly with tap water. Washed RaPM were allowed to sun dry for $18 \mathrm{~h}$ and milled using a commercial mill into flour. The flour was stored in an airtight container at room temperature $\left(25 \pm 1^{\circ} \mathrm{C}\right)$ for later use.

Preparation of beef sausages using RaPMF

Table 1 shows the ingredients and composition of the various treatments. RaPMF substituted ground beef at 0,5 , 10 , and $15 \%$ on $\mathrm{kg}$ basis. Meat (beef) samples were ground using a $5 \mathrm{~mm}$ mincer (Model star, Telleres Rammon, Spain) and comminuted using a bowl chopper (Model 30, Telleres Rammon, Spain), during which spices and other ingredients as shown in Table 1 were added. The final product was transferred into a hydraulic stuffer (Model 30, Telleres Rammon, Spain) and stuffed into casings. The sausages were manually linked into approximately $100 \mathrm{~mm}$ lengths and smoked at $105^{\circ} \mathrm{C}$ for $30 \mathrm{~min}$ in a smoker (Model HCR700L, ABAD, aquinaria (LAINT), Spain).

After smoking, they were scalded at $55{ }^{\circ} \mathrm{C}$ for $20 \mathrm{~min}$ and allowed to cool, packaged, and stored at $-18 \pm 1^{\circ} \mathrm{C}$ for further analysis. Figure 4 shows pearl millet beef sausages hanging on a rack.

\section{pH and water activity (aw) of RaPMF beef sausages}

Ten (10) grams of each sausage was ground in mortar and pestle, and homogenized with $10 \mathrm{~mL}$ of distilled water. Following this, the probe of a digital calibrated $\mathrm{pH}$ meter (Crison Basic 20, Alella, Spain) was dipped into the solution to obtain the $\mathrm{pH}$ values. Analyses were carried out in triplicates.

Water activity determination was carried out on $2.5 \mathrm{~g}$ of beef sausages using a water activity meter (Model Labswiftaw, Novasina AG, Switzerland) at room temperature (25 $\left.\pm 1{ }^{\circ} \mathrm{C}\right)$. All measurements were done in triplicates.

\section{Color measurements of RaPMF beef sausages}

The surface color of RaPMF beef sausages was measured using a colorimeter (CR 400 Konica Minolta Inc, Japan) equipped with a DP-400 data processor. The equipment was calibrated with a standard white plate at D65 illumination $(\mathrm{Y}=80.1, \mathrm{x}=0.3219, \mathrm{y}=0.3394)$. The Commission Internationale de l'Eclairage (CIE) lightness $\left(L^{*}\right)$, redness $\left(a^{*}\right)$, and yellowness $\left(b^{*}\right)$ values were measured on the surface of the sausage samples. Colour measurement was done according to CIE (1986). Measurements were done in triplicates and on days $0,7,14$ and 21 .

\section{Proximate composition of RaPMF beef sausages}

Proximate composition was done according to the Association of Official Analytical Chemists (AOAC) (2000). Kjeldahl apparatus (method 954.01), Soxhlet apparatus (method 920.39), furnace (method 942.09), and oven drying (method 930.15) were used for protein, fat, ash, and moisture contents determination, respectively. Total carbohydrates were calculated using the formula $100-(\%$ protein $+\%$ fat $+\%$ ash $\%+$ moisture $)$. Analyses were carried out in triplicates.

\section{Mineral analysis of RaPMF beef sausages}

Mineral analysis of the beef sausages was done using a slight according to the method used by Adua et al. (2020). Briefly, $2 \mathrm{~mL}$ perchloric acid and $10 \mathrm{~mL}$ concentrated $\mathrm{H}_{2} \mathrm{SO}_{4}$ was added to $1 \mathrm{~g}$ of beef sausage in a digestion tube. 
Table 1 Ingredients and composition of raw pearl millet flour beef sausages (RaPMFS)

\begin{tabular}{lcccc}
\hline \multirow{2}{*}{ Ingredients } & \multicolumn{3}{c}{ Treatments } \\
\cline { 2 - 5 } & $\mathbf{0 \%}$ RaPMF & 5\% RaPMF & $\mathbf{1 0 \%}$ RaPMF & 15\% RaPMF \\
\hline Beef (kg) & 2.00 & 1.90 & 1.80 & 1.70 \\
RaPMF (g) & 0.00 & 0.10 & 0.20 & 0.30 \\
Curing salt (g) & 0.03 & 0.03 & 0.03 & 0.03 \\
Adobo (g) & 0.002 & 0.002 & 0.002 & 0.002 \\
White pepper (g) & 0.004 & 0.004 & 0.004 & 0.004 \\
Black pepper (g) & 0.004 & 0.004 & 0.004 & 0.004 \\
Chilli pepper (g) & 0.001 & 0.001 & 0.001 & 0.001 \\
Phosphate (g) & 0.01 & 0.01 & 0.01 & 0.01 \\
Ice cubes (g) & 0.14 & 0.14 & 0.14 & 0.14 \\
Soy oil (g) & 0.26 & 0.26 & 0.26 & 0.26 \\
\hline
\end{tabular}

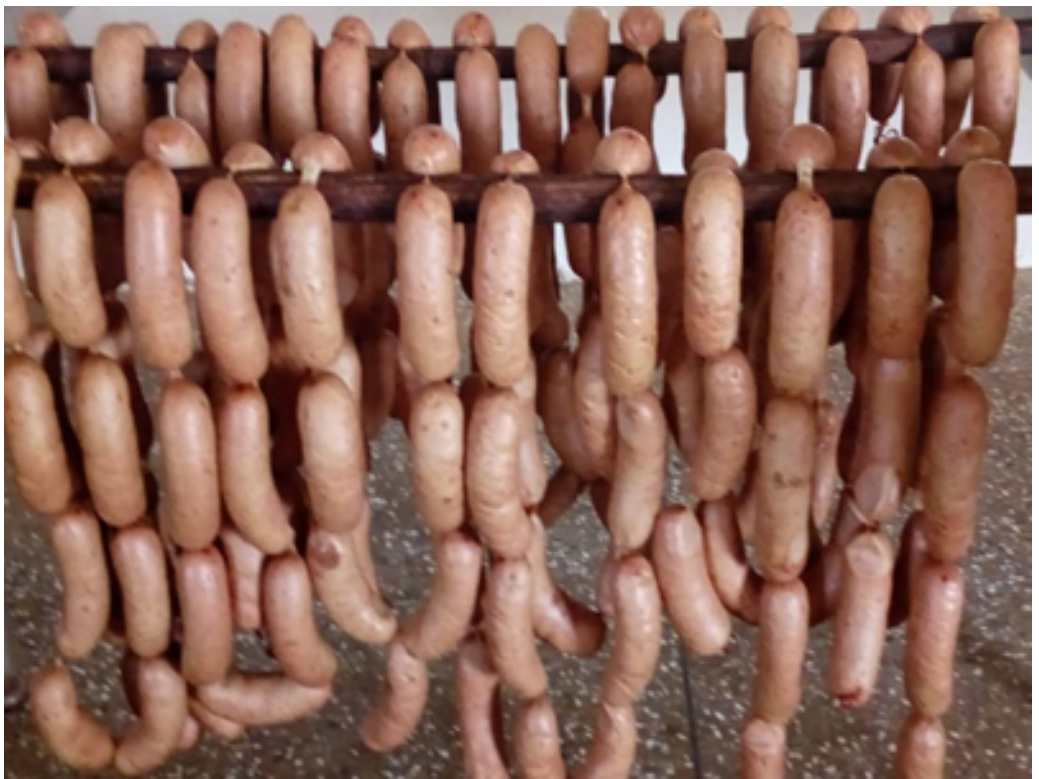

Figure 4 Pearl millet beef sausages.

They were heated until the solution turned clear at a temperature of $350{ }^{\circ} \mathrm{C}$. It was cooled, $2 \mathrm{~mL}$ of hydrogen peroxide was added, and top up with distilled water to the $50 \mathrm{~mL}$ mark. The solution was measured using an Atomic Absorption Spectrometer (AAS model novAA 400 P, Analytik Jena AG, Germany) to determine the various nutrients. Analyses were carried out in triplicates.

Peroxide value determination of RaPMF beef sausages

Peroxide value was determined using a slightly modified method of Salih et al. (1989), Abu et al. (2019), and Adua et al. (2020). Briefly, $10 \mathrm{~g}$ of the sausage was added to $30 \mathrm{~mL}$ hexane and agitated for $60 \mathrm{~min}$ at $250 \mathrm{rpm}$. It was then transferred into a $50 \mathrm{~mL}$ falcon tube and centrifuge for $5 \mathrm{~min}$ at $3000 \mathrm{rpm}$. The residues were then evaporated in an evaporator with $5 \mathrm{~mL}$ acetic acid-chloroform solution and later with $10 \mathrm{ml}$ acetic acid-chloroform solution. One (1) $\mathrm{mL}$ of saturated potassium iodide solution was added to the extracted samples in a $100 \mathrm{~mL}$ Erlenmeyer flask. And then, $5 \mathrm{~mL}$ of $1 \%$ starch soluble solution was added and the resulting mixture was titrated against $0.01 \mathrm{~N}$ sodium thiosulfate solution $\left(\mathrm{Na}_{2} \mathrm{~S}_{2} \mathrm{O}_{3}\right)$ until an endpoint was obtained, that is, color change from orange to a transparent color. A blank test was used for calibration. The peroxide value was calculated as:
Where:

$\mathrm{V}_{1}=$ titre value of sample; $\mathrm{V}_{0}=$ titre value of blank; $\mathrm{S}=$ weight of sample; $\mathrm{N}=$ normality of sodium thiosulfate. Measurements were taken on week 1, week 2, and week 3, and were carried out in triplicates.

\section{Water holding capacity of RaPMF beef sausages}

The water holding capacity was done using a slightly modified procedure of Heywood et al. (2002). In brief, $2.5 \mathrm{~g}$ of each sample was placed in a pre-weighed $50 \mathrm{~mL}$ centrifuge tube and $10 \mathrm{~mL}$ distilled water was added. They were thoroughly mixed, allowed to stand for $30 \mathrm{~min}$ at room temperature, and centrifuge at $3700 \mathrm{rpm}$ for $30 \mathrm{~min}$ using Hettich ROTOFIX 32A Centrifuge, Germany. After centrifugation, the supernatant was decanted and the sample weight was taken. Percentage water holding capacity was calculated according to the following equation:

$$
W H C(\%)=\frac{D w-S w}{S w} \times 100
$$

Where:

Dw - is the decant weight of the sample after centrifugation; $\mathrm{Sw}-$ is the sample weight. Analyses were carried out in triplicates. 


\section{Cooking loss of RaPMF beef sausages}

Cooking loss of the beef sausages was done according to Lee et al. (2008). Sausages were weighed (Wr) and cooked to obtain a core temperature of $70{ }^{\circ} \mathrm{C}$ at a temperature of $150^{\circ} \mathrm{C}$. Cooked sausages were allowed to cool to room temperature and reweighed (Wc). The cooking loss percentage was determined using the equation:

$$
\text { Cooking loss }(\%)=\frac{W r-W c}{W r} \times 100
$$

Where:

$\mathrm{Wr}=$ weight of raw sausage; Wc $=$ weight of cooked sausage. Analyses were carried out in triplicates.

\section{Sensory analysis of RaPMF beef sausages}

Before this, the sausages were grilled in an electric oven (Turbofan Blue Seal, UK) at a temperature of $105^{\circ} \mathrm{C}$ for $45 \mathrm{~min}$. Grilled beef sausages were cut into $2 \mathrm{~cm}$ sizes and wrapped in coded aluminum foil for sensory evaluation using 15 trained panelists (British Standard Institute Guidelines, 1993). Beef sausages were assessed using a 9-point hedonic scale, that is, 1: extremely liked to 9 disliked for color, flavor liking, flavor intensity, juiciness, taste, tenderness, texture, and overall liking. Sensory evaluations were done on weeks 1, 2, and 3.

Number of samples analyzed

Thirty-six (36) raw pearl millet flour (RaPMF) beef sausages were analyzed. The samples comprised of 9 each of $0,5,10$, and $15 \%$ RAMPF beef sausages.

Number of repeated analyses

The experimental analysis was triplicated.

Number of experiment replication

The entire experiment was triplicated.

The production cost of RaPMF beef sausages

The cost of producing a kilogram of beef sausages with and without raw pearl millet was determined according to Yaro et al. (2021). The cost of each inclusion level $(0,5$, 10 , and $15 \%$ ) was determined as a proportion of the respective kilogram cost, thus the cost of beef, spices, curing salt, and ice cubes for processing a kilogram of beef sausage.

\section{Statistical Analysis}

Data analysis was performed using one-way analysis of variance in Genstat Discovery $4^{\text {th }}$ Edition. Significant differences were determined at a 5\% significant level using Tukey studentized range test.

\section{RESULTS AND DISCUSSION}

The cooking loss, water holding capacity, $\mathrm{pH}$, water activity, and peroxide value of the beef sausages can be found in Table 2 . The cooking loss, $\mathrm{pH}$, and water activity of the beef sausages differed significantly $(p<0.05)$ from each other. However, the water holding capacity and peroxide value of the beef sausages did not differ $(p>0.05)$ from each other. The values ranged from $18.76 \pm 0.36$ to $26.74 \pm 1.18 \%, 1.18 \pm 0.07$ to $1.24 \pm 0.14 \%, 5.94 \pm 0.02$ to $6.03 \pm 0.01,0.805 \pm 0.002$ to $0.815 \pm 0.002,1.917$ to 3.542 meq. $\mathrm{kg}^{-1}$ for cooking loss, water holding capacity, $\mathrm{pH}$, water activity, and peroxide value, respectively. The instrumental color (lightness, redness, and yellowness) measurements of the beef sausages are presented in Table
3. The lightness of the beef sausages differed significantly $(p<0.05)$ on day 14 , redness on days 0,7 , and 14 , and yellowness on days 7,14 , and 21 . The instrumental color measurements of the beef sausages ranged from 50.22 to 55.64 (lightness), 7.14 to 8.73 (redness), and 18.17 to 22.69 (yellowness). Meat products formulated with food resources to improve their nutritional compositions and to promote good health upon consumption are essential. This is because the consumption of meat products in some cases has been associated with cardiovascular and other related diseases (Alisson-Silva et al., 2016; Battaglia et al., 2015). Millets have been reported to be a gluten-free cereal grain with sufficient protein, fiber, and antioxidants contents (Lang, 2020; Taylor and Emmambux, 2008) which when incorporated into sausages, will promote better nutrient composition and consequently health benefit. Meat products formulated with other food resources also bring diversity in meat consumption, ensure responsible consumption and cater to the increasing population that has less time for food preparation (Pintado and DelgadoPando, 2020; Yaro et al., 2021).

In this study, the water holding capacity and peroxide value were not influenced by the use of raw pearl millet flour in the beef sausages. Water holding capacity contributes to and influences the juiciness and tenderness of meat products (Cheng and Sun, 2008). Serdaroglu et al. (2018) found higher water holding capacity for beef patties formulated with dried pumpkin pulp and seed. The nonsignificant differences in the peroxide values mean that beef sausages with or without raw pearl millet flour are equally stable to rancidity, which is a major cause of unpleasant smell, taste, and flavor in meat products (Pereira and Abreu, 2018). The peroxide values recorded in this work were far below or not above $10 \mathrm{meq} / \mathrm{kg}$, the peroxide value at which rancidity is eminent (Feiner, 2006; Pereira and Abreu, 2018). The cooking loss, $\mathrm{pH}$, water activity, and some instrumental color parameters were influenced by the use of raw pearl millet flour. Generally, raw pearl millet flour increased the $\mathrm{pH}$ of the beef sausages and decreased the water activity, but within the recommended $\mathrm{pH}$ and water activity range for meat products (Feiner, 2006; Warris, 2010). The $\mathrm{pH}$ and water activity as found in this study will limit the growth of microorganisms and improve on the shelf life of the beef sausages. The cooking loss of the beef sausages decreased with the increasing amount of raw pearl millet, therefore, raw pearl millet flour improved the yield of the sausages during cooking. Colour is an important factor when it comes to consumers' acceptance of meat and meat products.

The lightness of the beef sausages was influenced on day 14 , redness on days 0,7 , and 14 , and the yellowness on days 7, 14, and 21. Myoglobin is responsible for the redness of meat and meat products. Consumers prefer red meat color for certain meat products and attribute it to freshness (Warris, 2010). Raw pearl millet at a high inclusion level $(15 \%)$ reduced the redness of the beef sausages except on day 21 where significant differences did not occur. The natural color of the pearl millet used which was grey is responsible for the reduction in the red color. The raw pearl millet diluted the red color of meat and reduced myoglobin and red coloration. 
Table 2 Physicochemical properties of raw pearl millet flour beef sausages (RaPMFS).

\begin{tabular}{|c|c|c|c|c|c|c|c|}
\hline \multirow{3}{*}{$\begin{array}{c}\text { Treatment } \\
(\%)\end{array}$} & \multicolumn{7}{|c|}{ Parameters } \\
\hline & \multirow{2}{*}{$\begin{array}{c}\text { Cooking loss } \\
(\%)\end{array}$} & \multirow{2}{*}{$\begin{array}{c}\text { Water } \\
\text { holding } \\
\text { capacity (\%) }\end{array}$} & \multirow[t]{2}{*}{ pH } & \multirow[t]{2}{*}{ Water activity } & \multicolumn{3}{|c|}{ Peroxide value (meq/kg) } \\
\hline & & & & & Week 1 & Week 2 & Week 3 \\
\hline $0 \%$ RaPMFS & $25.00 \pm 0.41^{\mathrm{a}}$ & $1.24 \pm 0.14$ & $5.94 \pm 0.02^{\mathrm{c}}$ & $0.812 \pm 0.002^{\mathrm{ab}}$ & 3.542 & 3.305 & 3.175 \\
\hline $5 \%$ RaPMFS & $26.74 \pm 1.18^{\mathrm{a}}$ & $1.22 \pm 0.06$ & $6.00 \pm 0.01^{\mathrm{b}}$ & $0.815 \pm 0.002^{\mathrm{a}}$ & 3.155 & 3.405 & 3.271 \\
\hline $10 \% \mathrm{RaPMFS}$ & $21.48 \pm 1.28^{\mathrm{b}}$ & $1.18 \pm 0.07$ & $5.98 \pm 0.00^{\mathrm{b}}$ & $0.805 \pm 0.002^{b}$ & 3.289 & 3.369 & 3.202 \\
\hline $15 \% \mathrm{RaPMFS}$ & $18.76 \pm 0.36^{\mathrm{c}}$ & $1.22 \pm 0.07$ & $6.03 \pm 0.01^{\mathrm{a}}$ & $0.807 \pm 0.004^{\mathrm{b}}$ & 3.855 & 2.188 & 1.917 \\
\hline$p$-value & $<0.001$ & 0.916 & $<0.001$ & 0.005 & 0.911 & 0.397 & 0.346 \\
\hline
\end{tabular}

Note: Values are means \pm standard deviation, values with different superscripts under the same column are significantly different $(\mathrm{p}<0.05)$.

Table 3 Instrumental colour measurements of raw pearl millet flour beef sausages (RaPMFS).

\begin{tabular}{|c|c|c|c|c|c|}
\hline \multirow[b]{2}{*}{ Parameter } & \multirow{2}{*}{ Treatment } & \multicolumn{4}{|c|}{ Storage time (days) ${ }^{1}$} \\
\hline & & $\mathbf{0}$ & 7 & 14 & 21 \\
\hline \multirow{5}{*}{ Lightness $\left(\mathrm{L}^{*}\right)$} & $0 \%$ RaPMFS & $53.69 \pm 1.97$ & $53.48 \pm 0.38$ & $52.83 \pm 0.91^{\mathrm{ab}}$ & $53.11 \pm 1.47$ \\
\hline & $5 \%$ RaPMFS & $52.47 \pm 1.66$ & $54.87 \pm 1.71$ & $50.22 \pm 1.53^{\mathrm{b}}$ & $55.98 \pm 1.21$ \\
\hline & $10 \%$ RaPMFS & $53.80 \pm 0.76$ & $55.01 \pm 0.53$ & $55.64 \pm 0.47^{\mathrm{a}}$ & $55.47 \pm 1.17$ \\
\hline & $15 \%$ RaPMFS & $50.31 \pm 1.96$ & $55.45 \pm 0.09$ & $54.35 \pm 1.71^{\mathrm{a}}$ & $55.72 \pm 1.35$ \\
\hline & $p$ value & 0.320 & 0.130 & 0.050 & 0.400 \\
\hline \multirow{5}{*}{ Redness (a*) } & $0 \%$ RaPMFS & $7.99 \pm 0.12^{\mathrm{ab}}$ & $8.50 \pm 0.48^{\mathrm{ab}}$ & $8.34 \pm 0.06^{\mathrm{a}}$ & $8.09 \pm 0.60$ \\
\hline & $5 \%$ RaPMFS & $8.48 \pm 0.21^{\mathrm{a}}$ & $8.73 \pm 0.40^{\mathrm{a}}$ & $8.33 \pm 0.16^{\mathrm{a}}$ & $8.20 \pm 0.46$ \\
\hline & $10 \%$ RaPMFS & $7.97 \pm 0.28^{\mathrm{ab}}$ & $8.40 \pm 0.17^{\mathrm{ab}}$ & $8.07 \pm 0.42^{\mathrm{a}}$ & $8.44 \pm 0.37$ \\
\hline & $15 \%$ RaPMFS & $7.85 \pm 0.25^{b}$ & $7.30 \pm 0.70^{\mathrm{b}}$ & $7.25 \pm 0.30^{\mathrm{b}}$ & $7.14 \pm 0.64$ \\
\hline & $p$ value & 0.040 & 0.030 & 0.000 & 0.070 \\
\hline \multirow{5}{*}{$\begin{array}{l}\text { Yellowness } \\
\left(b^{*}\right)\end{array}$} & $0 \%$ RaPMFS & $20.53 \pm 0.51$ & $18.91 \pm 0.35^{\mathrm{c}}$ & $18.31 \pm 0.18^{\mathrm{c}}$ & $18.17 \pm 0.50^{\mathrm{c}}$ \\
\hline & $5 \%$ RaPMFS & $20.90 \pm 0.46$ & $19.94 \pm 0.49^{b}$ & $18.46 \pm 1.04^{\mathrm{bc}}$ & $19.09 \pm 1.13^{\mathrm{bc}}$ \\
\hline & $10 \%$ RaPMFS & $21.96 \pm 0.74$ & $21.25 \pm 0.36^{\mathrm{a}}$ & $20.14 \pm 0.83^{\mathrm{ab}}$ & $20.71 \pm 0.60^{\mathrm{ab}}$ \\
\hline & $15 \%$ RaPMFS & $21.51 \pm 1.34$ & $21.56 \pm 0.22^{\mathrm{a}}$ & $21.44 \pm 0.33^{\mathrm{a}}$ & $22.69 \pm 1.36^{\mathrm{a}}$ \\
\hline & $p$ value & 0.240 & 0.000 & 0.000 & 0.000 \\
\hline
\end{tabular}

Note: Values are means \pm standard deviation, values with different superscripts under the same column are significantly different $(p<0.05) ;{ }^{1}$ storage at $-18{ }^{\circ} \mathrm{C}$.

Table 4 Proximate compositions of raw pearl millet flour beef sausages (RaPMFS).

\begin{tabular}{lccccc}
\hline \multirow{2}{*}{ Treatments } & \multicolumn{5}{c}{ Parameters } \\
\cline { 2 - 6 } & Moisture (\%) & Ash (\%) & Fat (\%) & Protein (\%) & Carbohydrate (\%) \\
\hline 0\% RaPMFS & $68.42 \pm 0.43^{\mathrm{a}}$ & $4.47 \pm 0.57$ & $5.53 \pm 3.22$ & $18.81 \pm 1.50$ & $2.77 \pm 1.70$ \\
$5 \%$ RaPMFS & $65.91 \pm 0.75^{\mathrm{b}}$ & $3.85 \pm 1.31$ & $8.19 \pm 2.11$ & $19.25 \pm 1.22$ & $2.80 \pm 1.58$ \\
$10 \%$ RaPMFS & $65.03 \pm 1.13^{\mathrm{b}}$ & $5.00 \pm 0.28$ & $6.63 \pm 2.68$ & $16.90 \pm 1.35$ & $6.44 \pm 3.64$ \\
$15 \%$ RaPMFS & $62.14 \pm 0.60^{\mathrm{c}}$ & $5.24 \pm 1.13$ & $9.86 \pm 0.56$ & $17.83 \pm 1.39$ & $4.93 \pm 0.26$ \\
$p$ - value & $<0.001$ & 0.326 & 0.206 & 0.232 & 0.187 \\
\hline
\end{tabular}

Note: Values are means \pm standard deviation, values with different superscripts under the same column are significantly different

$(p<0.05)$.

Table 5 Mineral compositions of raw pearl millet flour beef sausages (RaPMFS).

\begin{tabular}{|c|c|c|c|c|}
\hline \multirow{2}{*}{ Treatments } & \multicolumn{4}{|c|}{ Parameters } \\
\hline & Magnesium (mg.kg ${ }^{-1}$ ) & Calcium (mg.kg $\left.{ }^{-1}\right)$ & Potassium (mg.kg ${ }^{-1}$ ) & Zinc (mg.kg $\left.{ }^{-1}\right)$ \\
\hline $0 \%$ RaPMFS & $594.99 \pm 0.94^{\mathrm{d}}$ & $64.26 \pm 0.12^{\mathrm{d}}$ & $1137.46 \pm 1.24^{\mathrm{b}}$ & $33.96 \pm 0.07^{\mathrm{a}}$ \\
\hline $5 \%$ RaPMFS & $712.66 \pm 1.13^{\mathrm{b}}$ & $80.78 \pm 0.53^{c}$ & $1072.52 \pm 0.91^{\mathrm{d}}$ & $33.45 \pm 0.13^{\mathrm{a}}$ \\
\hline $10 \%$ RaPMFS & $670.54 \pm 0.60^{c}$ & $86.54 \pm 0.54^{\mathrm{b}}$ & $1116.63 \pm 1.62^{\mathrm{c}}$ & $33.39 \pm 0.41^{\mathrm{a}}$ \\
\hline $15 \%$ RaPMFS & $795.73 \pm 2.19^{\mathrm{a}}$ & $99.11 \pm 0.93^{\mathrm{a}}$ & $1156.90 \pm 1.26^{\mathrm{a}}$ & $30.61 \pm 0.04^{\mathrm{b}}$ \\
\hline$p$-value & $<0.001$ & $<0.001$ & $<0.001$ & $<0.001$ \\
\hline
\end{tabular}

Note: Values are means \pm standard deviation, values with different superscripts under the same column are significantly different

$(p<0.05)$ 
Similarly, Argel et al. (2020) found that green pea and chickpea flour emulsions used in pork patties lowered redness in the products. Also, Serdaroglu et al. (2018) reported that dried pumpkin pulp and seed lowered the redness of beef patties. The natural color of raw pearl millet also influenced the yellowness of the beef sausages especially during storage in that the beef sausages with raw millet flour were more yellow than the $0 \%$ RaPMF beef sausage. Green pea and chickpea flour emulsions also increased the yellowness of pork patties (Argel et al., 2020). However, this natural-color did not affect the lightness of the beef sausages except on day 14. The lightness, redness, and yellowness recorded in this study were higher than values recorded for uncooked meatballs during storage at $4{ }^{\circ} \mathrm{C}$ for 6 days (Ergezer et al., 2014).

The proximate composition results for the beef sausages are presented in Table 4. There were no significant differences $(p>0.05)$ in the ash, carbohydrate, fat, and protein contents of the beef sausages. However, the moisture content of the $0 \%$ RaPMF beef sausages was significantly higher $(p<0.05)$ than the 0,5 , and $15 \%$ RaPMF beef sausages. The results ranged from $62.14 \pm 0.60$ to $68.42 \pm 0.43 \%$ (moisture), $3.85 \pm 1.31$ to $5.24 \pm 1.13 \%$ (ash), $5.53 \pm 3.22$ to $9.86 \pm 0.56 \%$ (fat), $16.90 \pm 1.35$ to 19.25 $\pm 1.22 \%$ (protein) and $2.77 \pm 1.70$ to $6.44 \pm 3.64 \%$ (carbohydrate).

Incorporating raw pearl millet flour into beef sausages did not negatively affect the ash, fat, protein, and carbohydrate contents, but reduced the moisture content. This means raw pearl millet flour up to $15 \%$ can be used for beef sausage preparation without adverse effects on the proximate composition. A similar observation was made by Yaro et al. (2021). Yaro et al. (2021) reported differences in the moisture and protein content of roasted pearl millet flour beef sausages, but not the ash, fat, and carbohydrate contents. Amadi (2020) found significant differences in the moisture, protein, ash, carbohydrates, and fat content of full-fat soy flour beef sausages. Also, the inclusion of soy and finger millet flours in beef sausages increased the moisture, crude fat, crude protein, crude ash, and crude fiber contents (Behailu and Abebe, 2020).

The mineral composition of the beef sausages is shown in Table 5. There were significant differences $(p<0.05)$ in all the minerals measured. The iron, magnesium, and calcium contents were significantly higher $(p>0.05)$ in the 5,10 , and $15 \%$ RaPMF beef sausages than the $0 \%$ RaPMF beef sausages. The $15 \%$ RaPMF beef sausages had the highest $(p<0.05)$ potassium and least $(p<0.05)$ zinc contents. The $5 \%$ RaPMF beef sausages had the lowest $(p<0.05)$ potassium content. The minerals in the beef sausages also ranged from $594.99 \pm 0.94$ to $795.73 \pm 2.19 \mathrm{mg} \cdot \mathrm{kg}^{-1}$ (magnesium), $64.26 \pm 0.12$ to $99.11 \pm 0.93 \quad \mathrm{mg} \cdot \mathrm{kg}^{-1}$ (calcium), $1072.52 \pm 0.91$ to $1156.90 \pm 1.26 \mathrm{mg} \cdot \mathrm{kg}^{-1}$ (potassium) and $30.61 \pm 0.04$ to $33.96 \pm 0.07 \mathrm{mg} . \mathrm{kg}^{-1}$ (zinc). Developing beef sausages with raw pearl millet flour increased the iron, magnesium, calcium, and potassium contents. Thus, raw pearl millet flour for sausage development positively influenced the mineral composition of beef sausages. The zinc contents were similar except for beef sausages developed with $15 \%$ raw pearl millet flour. The calcium, magnesium, and zinc contents of the beef sausages recorded in this study were higher than those reported by Amadi (2020) in full-fat soy flour beef sausages. The magnesium, calcium, potassium, and zinc contents were similar to those reported by Yaro et al. (2021) in roasted pearl millet flour beef sausages.

The sensory properties of the beef sausages are shown in Table 6. There were no significant differences $(p>0.05)$ in the color, flavor intensity, flavor liking (except week 2), texture, tenderness, juiciness, and overall liking of the beef sausages. Sensory scores for color, flavor intensity, flavor liking, texture, tenderness, juiciness, and overall liking ranged from $4.53 \pm 2.13$ to $6.47 \pm 0.92,4.73 \pm 1.75$ to 6.80 $\pm 1.27,5.53 \pm 1.96$ to $7.20 \pm 1.61,4.87 \pm 1.77$ to $6.00 \pm 1.51$, $4.93 \pm 2.05$ to $6.53 \pm 1.19,5.20 \pm 1.37$ to $6.33 \pm 1.40$ and 5.93 \pm 1.16 to $7.53 \pm 1.36$, respectively. The color, flavor intensity, flavor liking, texture, tenderness, juiciness, and overall liking of the beef sausages were not influenced by raw pearl millet flour, except flavor liking and overall liking in week 2. Even though the flavor liking and overall liking were lower for the $15 \%$ RaPMF beef sausages in week 2 , this did not occur in week 3 . This means that beef sausages with or without raw pearl millet were equally acceptable. Also, the panelist described the color, flavor intensity, flavor liking, texture, tenderness, juiciness, and overall liking of the beef sausages as intermediate to slightly pale, intermediate to moderately strong, like slightly to like moderately, intermediate to slightly smooth, intermediate to moderately tender, intermediate to slightly juicy, and like slightly to like very much, respectively. It was interesting to find that, overall liking was scored better than the rest of the sensory attributes. Behailu and Abebe (2020) found that beef sausages formulated with $20 \%$ soy and finger millet flours were liked very much. The results of the present study also collaborate with that of Yaro et al. (2021) and Serdaroglu et al. (2018). Yaro et al. (2021) reported that roasted pearl millet flour did not cause changes in the sensory attributes of beef sausages. Serdaroglu et al. (2018) observed that sensory properties were not affected when dried pumpkin pulp and seed were used for beef patties.

The cost of producing the RaPMF beef sausages is presented in Table 7. The production cost in US dollars were $\$ 5.41, \$ 5.30, \$ 5.20$ and $\$ 5.08$ for $0 \%$ RaPMF, 5\% RaPMF, $10 \%$ RaPMF and 15\% RaPMF beef sausages, respectively. Price is important to factor consumers consider in purchasing meat and meat products. The costs of producing 5,10 , and $15 \%$ RaPMF beef sausages were lower than that of the $0 \%$ RaPMF beef sausages. This can be attributed to the lower cost of obtaining a kilogram of raw pearl millet as compared to a kilogram of lean beef. It also follows that RaPMF beef sausages will be more affordable compared with $0 \%$ RaPMF beef sausages.

Adua et al. (2020) formulated beef sausages with raw Citrullus vulgaris chaff and found that the incorporation of the raw Citrullus vulgaris chaff reduced the cost of producing the beef sausages. Similarly, Behailu and Abebe (2020) reported a reduction in the cost of producing beef sausages when soy and finger millet flours were used to prepare beef sausages. It has been reported that the expensive nature of meat products limits their patronage by average income earners (Malav et al., 2013). Therefore, the formulated RaPMF beef sausages will increase affordability and promote the consumption of beef sausages required to complement protein intake. 
Table 6 Sensory properties of raw pearl millet flour beef sausages (RaPMFS).

\begin{tabular}{|c|c|c|c|c|c|c|c|c|}
\hline Storage period $^{1}$ & Treatments (\%) & Colour & Flavour intensity & Flavour liking & Texture & Tenderness & Juiciness & Overall liking \\
\hline \multirow{4}{*}{ Week 1} & $0 \%$ RaPMFS & $5.67 \pm 2.13$ & $6.00 \pm 1.69$ & $6.47 \pm 1.81$ & $4.87 \pm 1.77$ & $4.93 \pm 2.05$ & $5.67 \pm 2.02$ & $6.20 \pm 1.90$ \\
\hline & $5 \%$ RaPMFS & $5.73 \pm 1.79$ & $6.13 \pm 1.69$ & $5.53 \pm 1.96$ & $5.27 \pm 1.83$ & $6.13 \pm 1.35$ & $6.33 \pm 1.40$ & $6.33 \pm 1.72$ \\
\hline & $10 \%$ RaPMFS & $5.40 \pm 1.55$ & $5.47 \pm 1.89$ & $6.33 \pm 1.11$ & $5.27 \pm 1.22$ & $6.27 \pm 1.34$ & $5.47 \pm 1.55$ & $6.67 \pm 1.45$ \\
\hline & $15 \%$ RaPMFS & $4.53 \pm 2.13$ & $4.73 \pm 1.75$ & $5.67 \pm 1.40$ & $5.67 \pm 1.59$ & $5.80 \pm 1.47$ & $5.20 \pm 1.37$ & $5.93 \pm 1.16$ \\
\hline \multirow[t]{2}{*}{$p-$ Value } & & 0.286 & 0.121 & 0.164 & 0.538 & 0.266 & 0.125 & 0.352 \\
\hline & $0 \%$ RaPMFS & $5.20 \pm 1.52$ & $6.80 \pm 1.27$ & $7.20 \pm 1.61^{\mathrm{a}}$ & $5.47 \pm 1.73$ & $5.40 \pm 1.81$ & $5.73 \pm 1.58$ & $7.53 \pm 1.36^{\mathrm{a}}$ \\
\hline \multirow[t]{3}{*}{ Week 2} & $5 \%$ RaPMFS & $5.20 \pm 1.52$ & $5.60 \pm 1.45$ & $6.47 \pm 1.51^{\mathrm{ab}}$ & $5.80 \pm 1.15$ & $6.27 \pm 1.34$ & $5.80 \pm 1.27$ & $6.60 \pm 1.50^{\mathrm{ab}}$ \\
\hline & $10 \%$ RaPMFS & $4.73 \pm 1.39$ & $5.47 \pm 1.51$ & $6.67 \pm 1.40^{\mathrm{ab}}$ & $5.47 \pm 1.36$ & $6.53 \pm 1.19$ & $5.93 \pm 1.16$ & $6.53 \pm 1.85^{\mathrm{ab}}$ \\
\hline & $15 \%$ RaPMFS & $5.13 \pm 1.77$ & $5.40 \pm 1.92$ & $6.13 \pm 0.92^{b}$ & $6.00 \pm 1.51$ & $5.67 \pm 1.59$ & $5.73 \pm 1.44$ & $6.40 \pm 1.40^{\mathrm{b}}$ \\
\hline \multirow[t]{2}{*}{$p$ - Value } & & 0.792 & 0.059 & 0.038 & 0.489 & 0.222 & 0.906 & 0.032 \\
\hline & 0\% RaPMFS & $6.47 \pm 0.92$ & $5.87 \pm 1.41$ & $6.47 \pm 1.73$ & $5.33 \pm 1.45$ & $6.20 \pm 1.42$ & $6.13 \pm 1.64$ & $6.73 \pm 1.98$ \\
\hline \multirow[t]{3}{*}{ Week 3} & $5 \%$ RaPMFS & $5.80 \pm 1.57$ & $5.67 \pm 0.90$ & $6.60 \pm 0.91$ & $5.67 \pm 1.29$ & $6.07 \pm 1.44$ & $5.67 \pm 1.63$ & $6.40 \pm 1.30$ \\
\hline & $10 \%$ RaPMFS & $6.13 \pm 1.19$ & $5.67 \pm 0.90$ & $5.93 \pm 1.22$ & $5.87 \pm 1.36$ & $6.53 \pm 0.74$ & $6.33 \pm 1.40$ & $6.67 \pm 1.54$ \\
\hline & $15 \%$ RaPMFS & $5.87 \pm 1.13$ & $5.60 \pm 1.12$ & $5.73 \pm 1.44$ & $5.80 \pm 1.86$ & $6.07 \pm 1.67$ & $5.53 \pm 1.51$ & $6.33 \pm 1.29$ \\
\hline$p-$ Value & & 0.546 & 0.908 & 0.257 & 0.668 & 0.606 & 0.411 & 0.480 \\
\hline
\end{tabular}

Note: Values are means \pm standard deviation, values with different superscripts under the same column are significantly different $(p<0.05)$.

Table 7 Formulation cost of raw pearl millet flour beef sausages (RaPMFS).

\begin{tabular}{|c|c|c|c|c|c|}
\hline Ingredient & $\begin{array}{l}\text { Amount } \\
\text { (US \$/kg) }\end{array}$ & $\begin{array}{c}\text { 0\% RaPMFS } \\
\text { (\$) }\end{array}$ & $\begin{array}{c}\text { 5\% RaPMFS } \\
\text { (\$) }\end{array}$ & $\begin{array}{c}\text { 10\% RaPMFS } \\
(\$)\end{array}$ & $\begin{array}{c}15 \% \text { RaPMFS } \\
\text { (\$) }\end{array}$ \\
\hline Minced beef & 4.46 & 4.46 & 4.24 & 4.02 & 3.79 \\
\hline Pearl millet & 9.61 & - & 0.04 & 0.09 & 0.13 \\
\hline Milling & 0.34 & - & 0.02 & 0.03 & 0.05 \\
\hline $\begin{array}{l}\text { Water for processing } \\
\text { millet }\end{array}$ & 0.17 & - & 0.01 & 0.02 & 0.03 \\
\hline Spice mix & 0.09 & 0.12 & 0.12 & 0.12 & 0.12 \\
\hline Curing salt & 0.09 & 0.09 & 0.09 & 0.09 & 0.09 \\
\hline Soy oil & 0.14 & 0.14 & 0.14 & 0.14 & 0.14 \\
\hline Casing & 0.51 & 0.51 & 0.51 & 0.51 & 0.51 \\
\hline Ice cube & 0.09 & 0.09 & 0.09 & 0.09 & 0.09 \\
\hline Transportation & 0.8 & - & 0.04 & 0.09 & 0.13 \\
\hline Total cost (US\$) & & 5.41 & 5.30 & 5.20 & 5.08 \\
\hline
\end{tabular}

\section{CONCLUSION}

Raw pearl millet flour can be used to replace up to $15 \%$ of lean meat in beef sausages without generally affecting the nutritional composition, physicochemical properties, and sensory evaluation. Raw pearl millet flour positively influenced the mineral composition of beef sausages. It also reduced the formulation cost of producing beef sausages. The cooking loss was at least for the 15\% RaPMF beef sausages. Millet showed great potential for sausage formulation and will make an appreciable contribution to a healthy diet. Phytochemical and microbial analyses are recommended for further research.

\section{REFERENCES}

Abu, A., Teye, G. A., Adzitey, F. 2019. Effects of sweet basil (Ocimum basilicum) leaf powder on the sensory and nutritional qualities of beef and frankfurter sausages. UDS International Journal of Development, vol. 6, no. 1, p. 84-91. https://doi.org/10.47740/332.UDSIJD6i

Adua, E. A., Adzitey, F., Huda, N. 2020. Nutritional composition, physiochemical analysis, sensory properties and economics of raw and roasted "niri" (Citrullus vulgaris) chaff extended beef sausages. Journal of Animal Health and Production, vol. 8, no. 2, p. 212-220. https://doi.org/10.17582/journal.jahp/2020/8.4.212.220 
Alisson-Silva, F., Kawanishi, K., Varki, A. 2016. Human risk of diseases associated with red meat intake: Analysis of current theories and proposed role for metabolic incorporation of a non-human sialic acid. Molecular Aspects of Medicine, vol. 51, p. 16-30. https://doi.org/10.1016/j.mam.2016.07.002

Amadi, A. O., 2020. Nutritional Effects of Full-Fat Soy Flour as an Extender on Cooked Beef Sausage Quality. Asian Food Science Journal, p. 44-53. https://doi.org/10.9734/afsj/2020/v17i330195

Argel, N. S., Ranalli, N., Califano, A. N., Andrés, S. C. 2020. Influence of partial pork meat replacement by pulse flour on physicochemical and sensory characteristics of low-fat burgers. Journal of the Science of Food and Agriculture, vol. 100, p. 3932-3941. https://doi.org/10.1002/jsfa.10436

Association of Official Analytical Chemists (AOAC). 2000. Methods of analysis of AOAC International. $17^{\text {th }}$ ed. MD, USA : AOAC International: Gaithersburg.

Battaglia, R. E., Baumer, B., Conrad, B., Darioli, R., Schmid, A., Keller, U. 2015. Health risks associated with meat consumption: A review of epidemiological studies. International Journal for Vitamin and Nutrition Research, vol. 85, vol. 1-2, p. 70-80. https://doi.org/10.1024/03009831/a000224

Behailu, B., Abebe, M. 2020. Effect of soybean and finger millet flours on the physicochemical and sensory quality of beef meat sausage. Asian Journal of Chemical Sciences, vol. 7, no. 1, p. 6-14. https://doi.org/10.9734/ajocs/2020/v7i119010

British Standard Institution Guidelines. 1993. Assessors for sensory analysis. Guide to selection, training and monitoring of selected assessors. United Kingdom : British standard institution London.

Cheng, Q., Sun, D. 2008. Factors affecting the water holding capacity of red meat products: A review of recent research advances. Critical Reviews in Food Science and Nutrition, vol. 48, no. $2, \quad$ p. $137-159$. https://doi.org/10.1080/10408390601177647

CIE. 1986. Colorimetry. $2^{\text {nd }}$ edition. Vienna : Commission International Del, Eclairage.

El-Magoli, S. B. M., Abd-Allah, M. A. 2014. Encyclopedia of Meat Sciences. $2^{\text {nd }}$ ed. Amsterdam, Netherland : Elsevier, p. 453-455. https://doi.org/10.1016/B978-0-12-384731-7.00197$\underline{5}$

Ergezer, H., Akcan, T., Serdaroglu, M. 2014. The effects of potato puree and bread crumbs on some quality characteristics of low fat meatballs. Korean Journal of Food Science and Animal Resources, vol. 34, no. 5, p. 561-569. https://doi.org/10.5851/kosfa.2014.34.5.561

Feiner, G. 2006. Meat Products Handbook: Practical Science and Technology. Boca Raton : Woodhead Publishing Limited, p. 19-32. ISBN 9781845691721.

Food and Agriculture Organization. 2013. Meat products with high levels of extenders and fillers. Available at: http://www.fao.org/tempref/docrep/fao/010/ai407e/ai407e07. pdf, accessed on 30/12/2020.

Food and Agriculture Organization. 2020. Sausage raw materials. Available

at: http://www.fao.org/3/x6556e/X6556E02.htm, accessed on 30/12/2020.

Heinz, G., Hautzinger, P. 2007. Meat processing technology for small to medium scale producers. Bangkok : FAO, RAP Publication 2007/20.

Heywood, A. A., Myers, D. J., Bailey, T. B., Johnson, L. A. 2002. Functional properties of low-fat soy flour produced by an extrusion-expelling system. Journal of the American Oil Chemists' Society, vol. 79, p. 1249-1253. https://doi.org/10.1007/s11746-002-0635-y
Kumar, R. R., Sharma, B. D., Kumar, M., Chidanandaiah, Biswas, A. K. 2007. Storage quality and shelf life of vacuumpackaged extended chicken patties. Journal of Muscle Foods, vol. 18 , no. 3 , p. 253-263. https://doi.org/10.1111/j.17454573.2007.00080.x

Lang, A. 2020. What is millet? Nutrition, benefits, and more. 1 p. Available at: https:/www.healthline.com/nutrition/whatis-millet\# noHeaderPrefixedContent, accessed on 30/12/2020.

Lee, M. A., Han, D. J., Jeong, J. Y., Choi, J. H., Choi, Y. S., Kim, H. Y. 2008. Effect of kimchi powder level and drying methods on quality characteristics of breakfast sausage. Meat $\begin{array}{llll}\text { Science, } & \text { vol. } & 80, & \text { p. }\end{array}$ https://doi.org/10.1016/j.meatsci.2008.03.010

Malav, O. P., Sharma, B. D., Talukder, S., Kumar, R. R. 2013. Economics of preparation of restructured chicken meat blocks extended with different vegetative extenders. Journal of Food Processing and Technology, vol. 4, no. 12, p. 1-4. https://doi.org/10.4172/2157-7110.1000282

Muthamilarasan, M., Dhaka, A., Yadav, R., Prasad, M. 2016. Exploration of millet models for developing nutrient rich graminaceous crops. Plant Science, vol. 242, p. 89-97. https://doi.org/10.1016/j.plantsci.2015.08.023

Nithiyanantham, S., Kalaiselvi, P., Mahomoodally, M. F., Zengin, G., Abirami, A., Srinivasan, G. 2019. Nutritional and functional roles of millets-A review. Journal of Food Biochemistry, vol. 43, no. 7, p. e12859. https://doi.org/10.1111/jfbc.12859

Ossom, R. N., Adzitey, F., Teye, G. A., Abu, A., Amagloh, F. K. 2020b. Sensory and nutritional qualities of beef sausages prepared with sweet potato puree as extender. Nigerian Journal of Animal Science, vol. 22, no. 1, p. 338-348.

Ossom, R. N., Teye, G. A. Adzitey, F. 2020a. Sensory and nutritional qualities of frankfurter sausages with sweet potato as extender. African Journal of Food, Agriculture, Nutrition and Development, vol. 20, no. 1, p. 15222-15234. https://doi.org/10.18697/ajfand.89.18720

Pereira, A. L. F., Abreu, V. K. G. A. 2018. Lipid peroxidation in meat and meat products. 1 p. Available at: https://www.intechopen.com/books/lipid-peroxidationresearch/lipid-peroxidation-in-meat-and-meat-products, accessed on 30/12/2020.

Pintado, T., Delgado-Pando, G. 2020. Towards more sustainable meat products: extenders as a way of reducing meat content. Foods, vol. 9, no. 8, p. 1044. https://doi.org/10.3390/foods9081044

Salih, A. M., Smith, D. M., Price, J. F., Dawson, L. E. 1989. Modified extraction 2-thiobarbituric acid method for measuring lipid oxidation in poultry. Poultry Science, vol. 66, no. 9, p. 1483-1488. https://doi.org/10.3382/ps.0661483

Serdaroglu, M., Kavusan, H. S., Ipek, G., Ozturk, B. 2018. Evaluation of the quality of beef patties formulated with dried pumpkin pulp and seed. Korean Journal of Food Science and Animal Resources, vol. 38, no. 1, p. 1-13. https://doi.org/10.5851/kosfa.2018.38.1.001

Stubbs, R. I., Morgan, J. B., Ray, K. F., Dolezal, H. G. 2002. Effect of supplemental vitamin E on color and case life of top lion steaks and ground chuck patties modified atmosphere case-ready retail packaging systems. Meat Science, vol. 61, no. 1, p. 1-5. https://doi.org/10.1016/S0309-1740(01)00148-6

Taylor, J. R. N., Emmambux, M. N. 2008. Gluten-free cereal products and beverages. Food Science and Technology, vol. 2008, p. 119-148. https://doi.org/10.1016/B978-0123737397.50008-3

Warris, P. D. 2010. Fats fatty acids in meat. In: meat science, an introductory text. Wallingford Oxford Shire, UK : CAB International, p. 77-96. 
Yadav, S., Yadava, R. 2008. Effects of using bengal gram flour and corn flour as extenders on physicochemical and nutritional quality of quail meat rolls. Veterinary Practice, vol. 9, no. 2, p. 150-153.

Yaro, J., Adzitey, F., Huda, N. 2021. Roasted pearl millet flour (RoPMF) improved the mineral composition of beef sausages. International Journal on Advanced Science, Engineering, Information and Technology, vol. 11, no. 2, p. 769-775. https://doi.org/10.18517/ijaseit.11.2.13703

\section{Funds:}

Funds for publication fee was by Universiti Malaysia Sabah, Malaysia.

\section{Acknowledgments:}

The authors acknowledge the support provided by the Staff of the Meat Units of University for Development Studies and Universiti Malaysia Sabah.

\section{Conflict of Interest:}

The authors declare no conflict of interest.

\section{Ethical Statement:}

Ethical approval is not applicable since no human or animal subjects were used.

\section{Contact Address:}

*Frederick Adzitey, University for Development Studies, Department of Animal Science, Box TL 1882, Tamale, Ghana, Tel.: +233249995310,

E-mail: adzitey@yahoo.co.uk

ORCID: https://orcid.org/0000-0002-8814-0272

Joseph Yaro, University for Development Studies, Department of Animal Science, Box TL 1882, Tamale, Ghana, Tel.: +233243461131,

E-mail: jaylizma@yahoo.com

Joseph Kudadam Korese, University for Development Studies, Department of Agricultural Mechanization and Irrigation Technology, Box TL 1882, Tamale, Ghana. Tel.: +233243491424 ,

E-mail: jkorese@uds.edu.gh

ORCID: https://orcid.org/0000-0001-9895-1717

Mohammad Halim Jeinie, Universiti Malaysia Sabah, Faculty of Food Science and Nutrition, Department of Food Service, 88400, Kota Kinabalu, Sabah, Malaysia,

E-mail: halimjeinie@ums.edu.my

ORCID: https://orcid.org/0000-0001-6394-922X

*Nurul Huda, Universiti Malaysia Sabah, Faculty of Food Science and Nutrition, Department of Food Science and Nutrition, 88400, Kota Kinabalu, Sabah, Malaysia; Universitas Sebelas Maret, Faculty of Agriculture, Department of Food Science and Technology, Jln. Ir. Sutami 36 A, Surakarta, Central Java, 57126, Indonesia; E-mail: drnurulhuda@ums.edu.my.

ORCID: https://orcid.org/0000-0001-9867-6401

Corresponding author: * 